DOI : https://doi.org/10.24123/jbt.v5i1.4029

\title{
REAKSI PASAR ATAS PANDEMI VIRUS CORONA PADA PERUSAHAAN LQ45 DI BURSA EFEK INDONESIA
}

\author{
Nabiell Ghibran ${ }^{1}$, Lukman Effendy $^{2}$, Indria Puspitasari Lenap ${ }^{3}$ \\ ${ }^{1,2,3}$ Universitas Mataram; Jalan Majapahit No. 62 Mataram, 081803656803 \\ Email : nabiel.ghibran@gmail.com ${ }^{l}$, lukman.effendy@unram.ac.id ${ }^{2}$, \\ indrialenap@unram.ac.id ${ }^{3}$
}

\begin{abstract}
The study was intended to analyze the reactions of Indonesia's capital markets on events Indonesia tested positive for the corona virus pandemic. The study adopted an 11day period of event study analysis. The population in this study is the entire company listed on the LQ45 index at the Indonesian stock exchange in February - June 2020. Sampling taken in this study uses an impressive sampling technique. Samples obtained by criteria on this research account number 42 companies. Variables used in this study are abnormal return and trading volume of activity. The study used paired sample t-test analysis methods. The research indicates that there was no significant difference between average abnormal return before and after the Indonesia announcement was positive the corona virus pandemic. This is indicated by the results of the significant paired sample ttest that have a value of $0.924>0.05$. Additionally, this study indicates that there was no significant difference in average trading volume activity before and after the events of the Indonesian announcement was positive that the corona virus pandemic. This is indicated by the results of the significant paired sample t-test that have a value of 0.936 >0.05.
\end{abstract}

Keywords : Event Study, Corona Virus Pandemic, Abnormal Return, Trading Volume Activity

\section{Pendahuluan}

Sebagai suatu instrumen ekonomi, pasar modal juga tidak lepas dari berbagai pengaruh lingkungan, baik lingkungan ekonomi maupun lingkungan non ekonomi. Pengaruh lingkungan ekonomi mikro seperti kinerja perusahaan, perubahan strategi perusahaan, pengumuman laporan keuangan atau dividen perusahaan selalu mendapat tanggapan dari pelaku pasar di pasar modal (Laili, 2017). Selain itu, pengaruh lingkungan non ekonomi juga dapat mempengaruhi suatu instrument ekonomi dan pasar modal. Adanya peristiwa bencana non alam seperti suatu wabah penyakit yang menyebar secara global dapat memicu pengaruh terhadap kondisi perekonomian beberapa negara. Awal tahun 2020 dunia dikejutkan dengan ancaman wabah penyakit baru yang dikenal dengan Virus Corona. Virus Corona yang oleh World Health Organization (WHO) diberi nama Coronavirus Disease 2019 (COVID-19) ini mulai muncul di Provinsi Hubei, Kota Wuhan, China, Desember 2019. Indonesia telah dinyatakan positif corona setelah Presiden Joko Widodo mengonfimasi bahwa dua orang warga Indonesia dinyatakan positif tertular virus corona. Pengumuman yang dikeluarkan oleh Presiden Joko Widodo pada 2 Maret 2020 ini membuat Indeks Harga Saham Gabungan (IHSG) melemah. IHSG terpantau melemah ketika berita corona di Indonesia beredar. Sebelumnya, pada 
pembukaan perdagangan Senin, (2/3/2020) IHSG sudah mulai menguat pada level $5.455,04$. Tercatat pada penutupan perdagangan Senin (2/3/2020), IHSG ditutup melemah 1,68\% pada level 5.361,24 (Bursa Efek Indonesia, 2020). Selain itu, kelompok 45 saham unggulan yang termasuk dalam indeks LQ45 juga turut mengalami koreksi yang cukup dalam. Secara year to date, indeks LQ45 mengalami koreksi sebesar -15,03\% (Otoritas Jasa Keuangan, 2020). Oleh karena itu, penelitian ini memilih indeks LQ45 dikarenakan perusahaan-perusahaan yang termasuk dalam indeks LQ45 dinilai dapat mencerminkan perusahaan-perusahaan dari berbagai sektor dengan likuiditas yang tinggi, kapitalisasi pasar yang besar dan memiliki fundamental perusahaan yang baik serta banyak diminati investor.

Pada penelitian ini, peneliti ingin menguji reaksi pasar atas pandemi virus corona pada perusahaan yang terdaftar pada indeks LQ45 di Bursa Efek Indonesia. Alat ukur yang digunakan dalam penelitian ini adalah Average Abnormal Return (AAR). Peneliti menggunakan $A A R$ karena $A A R$ digunakan untuk menggambarkan keseluruhan abnormal return selama periode event. Abnormal return merupakan selisih antara return sebenarnya dengan return yang diharapkan yang biasanya muncul akibat peningkatan aktivitas perdagangan yang signifikan. Menurut Andarini (2016) abnormal return positif menunjukkan bahwa return yang diterima lebih besar dari return yang diharapkan, sebaliknya apabila return yang diterima lebih kecil dari yang diharapakan maka disebut abnormal return negatif. Setiawan dan Bandi (2015) dalam penelitiannya tentang reaksi pasar terhadap perubahan dividen dengan indikator abnormal return dan trading volume activity menyatakan bahwa lebih baik menggunakan indicator trading volume activity untuk melihat reaksi pasar dibandingkan dengan abnormal return karena dalam penelitiannya hanya dividen tetap dan dividen inisiasi dengan indikator trading volume activity yang menunjukkan reaksi pasar yang signifikan. Hal ini menjadi motivasi peneliti untuk menggunakan trading volume activity sebagai salah satu alat ukur dalam penelitian ini.

Penelitian sejenis yang menganalisis reaksi pasar saham yang disebabkan oleh suatu peristiwa non ekonomi telah banyak dilakukan. Namun, dibeberapa penelitian yang menganalisis reaksi pasar atas peristiwa non ekonomi memiliki hasil yang berbeda-beda. Penelitian Feranita (2014) yang menganalisis reaksi pasar modal Indonesia terhadap bencana alam Tsunami di Aceh tanggal 26 Desember 2004 menemukan bahwa tidak terdapat perbedaan reaksi pasar sebelum dan sesudah bencana alam Tsunami di Aceh pada tanggal 26 Desember 2014 baik yang diukur menggunakan abnormal return maupun yang diukur menggunakan trading volume activity. Ernawati, Sari, dan Ananda (2019) yang meneliti tentang reaksi pasar modal dan pasar modal syariah terhadap kemenangan Jokowi 2019 (Jokowi's Effect) yang menemukan bahwa tidak adanya perbedaan average abnormal return yang signifikan antara sebelum dan sesudah tanggal pengumuman kemenangan Jokowi 2019. Hal yang sama ditemukan oleh penelitian Asshodiqi (2015); Bara dan Siswanto (2017); Bruno, Onali dan Schaeck (2018); Mubarok (2019); Riyadi, Sujito dan Rinawati (2019); Damayanti, Larasati dan Hana (2020).

Berbeda dengan hasil penelitian Wardani (2018) yang meneliti tentang pengaruh peristiwa politik (pemilu presiden dan pengumuman susunan kabinet) terhadap saham sektor industri di Bursa Efek Indonesia yang menemukan bahwa terdapat perbedaan yang signifikan pada abnormal return sebelum dan sesudah peristiwa politik. Rundegan, Mangantar, dan Maramis (2017) yang menganalisasis reaksi pasar atas pelantikan Sri Mulyani sebagai menteri keuangan 2016 menemukan bahwa terdapat pergerakan abnormal return dan trading volume activity yang signifikan. Hal yang sama ditemukan oleh Mehta (2014); Kadioglu, Telceken dan Ocal (2015); Liogu dan Sareang (2015); Kumar (2017); Rahmawati dan Effendy (2018); Liu, Sarkar, Kumar dan Jin (2016). 
Berdasarkan fenomena dan research gap di atas, maka peneliti tertarik untuk meneliti tentang reaksi pasar atas pandemi Virus Corona pada perusahaan LQ45 di Bursa Efek Indonesia. Adapun tujuan dari penelitian ini adalah untuk mengetahui perbedaan abnormal return dan trading volume activity sebelum dan sesudah masuknya pandemi virus corona di Indonesia. Hasil penelitian ini diharapkan dapat memberikan informasi kepada pengambil keputusan investasi tentang dampak kandungan informasi dari suatu peristiwa terhadap harga saham. Hal ini juga sebagai referensi oleh investor dalam menentukan waktu (timing) untuk berinvestasi berdasarkan peristiwa yang terjadi.

\section{Landasan Teori dan Pengembangan Hipotesis}

Informasi yang dipublikasikan sebagai suatu pengumuman akan memberikan sinyal bagi investor dalam pengambilan keputusan investasi (Laili, 2017). Dalam hal ini, pengumuman saat Indonesia dinyatakan sebagai salah satu negara yang terpapar virus corona dapat menimbulkan persepsi investor yang berbeda-beda. Persepsi dari investor dapat menimbulkan adanya reaksi pada pasar atas peristiwa yang terjadi. Indikator yang digunakan untuk mengukur adanya reaksi pasar pada penelitian ini adalah abnormal return dan trading volume activity.

Menurut Andarini (2016), Abnormal return yang bernilai positif menimbullkan arti terdapat reaksi pasar yang positif terhadap suatu peristiwa, sebaliknya abnormal return yang bernilai negatif menunjukkan reaksi negatif terhadap suatu peristiwa. Selain menggunakan indikator abnormal return, peneliti juga memilih indikator trading volume activity untuk mengukur reaksi pasar yang ditimbulkan oleh peristiwa pengumuman Indonesia dinyatakan positif corona. Setiawan dan Bandi (2015) menyatakan bahwa untuk melihat reaksi pasar lebih baik menggunakan indikator trading volume activity dari pada abnormal return. Selanjutnya, Munajat dan Nurfitriana (2021) menjelaskan bahwa volume perdagangan saham (trading volume activity) sebagai salah satu indikator reaksi pasar modal biasanya dikaitkan dengan suatu pergerakan harga saham. Kenaikan/penurunan volume perdagangan saham dapat menjadi suatu bentuk gambaran kondisi pasar secara umum. Hal tersebut dikarenakan volume perdagangan menggambarkan pertemuan supply dan demand transaksi saham.

Berdasarkan uraian teoritis dan hasil penelitian-penelitian terdahulu yang menguji pengaruh kandungan informasi dalam suatu peristiwa terhadap harga saham. Maka rerangka pemikiran yang dapat digambarkan dari penelitian ini adalah sebagai berikut : 


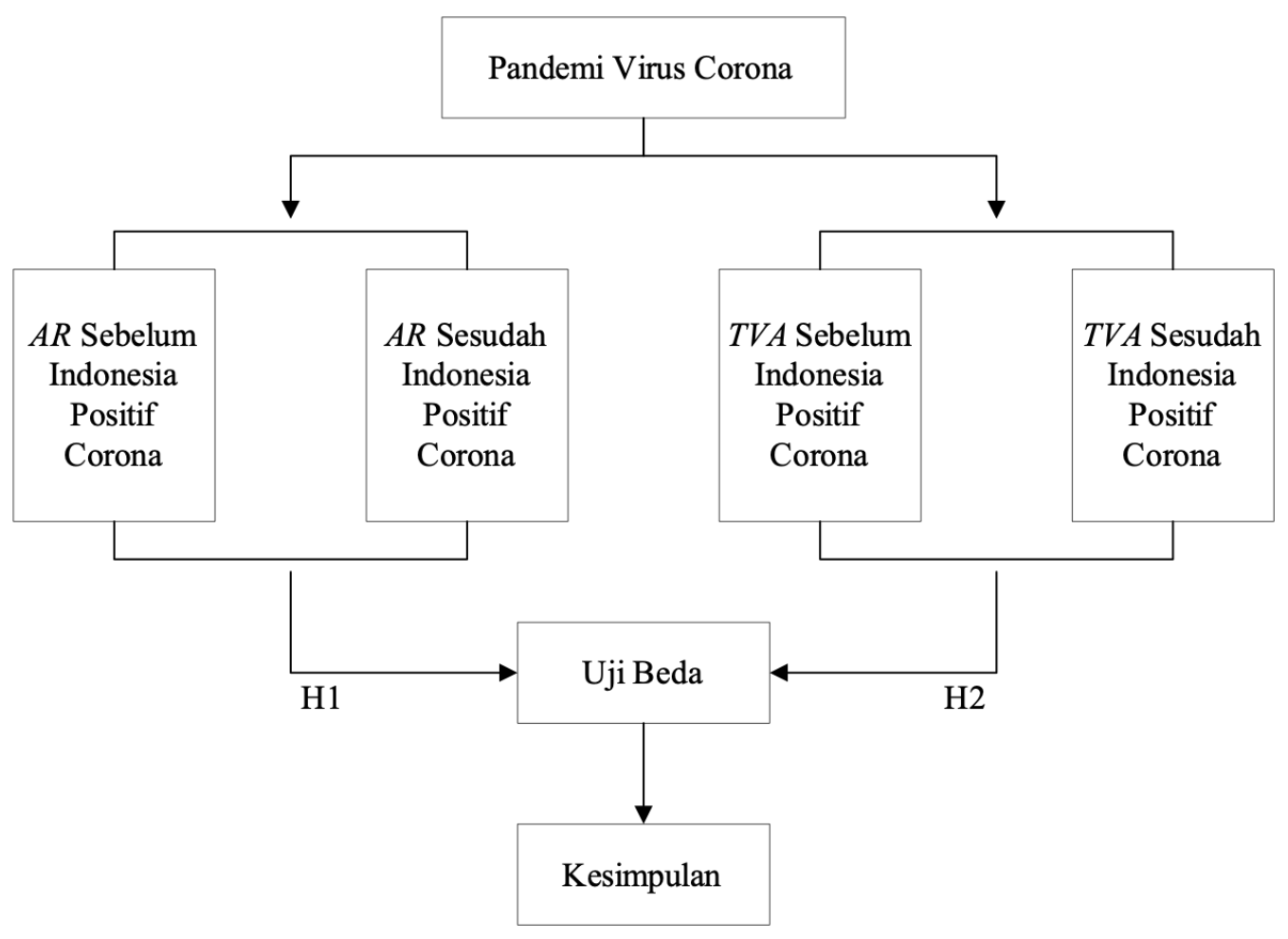

Gambar 1. Kerangka konseptual penelitian

\section{Pengembangan Hipotesis}

Reaksi pasar yang diukur dengan abnormal return sebelum dan sesudah Indonesia dinyatakan positif corona

Signaling theory menjelaskan bahwa suatu Informasi yang dipublikasikan sebagai suatu pengumuman akan memberikan sinyal bagi para investor dalam pengambilan keputusan investasi (Liogu dan Saerang, 2015). Informasi yang dapat memberikan sinyal kepada pelaku pasar dapat berupa informasi dari internal perusahaan maupun eksternal perusahaan. Informasi internal perusahaan dapat berupa kinerja perusahaan, perubahan strategi perusahaan, pengumuman laporan keuangan atau dividen perusahaan (Laili, 2017). Sedangkan, informasi eksternal perusahaan dapat berupa berbagai regulasi dan deregulasi ekonomi yang dikeluarkan pemerintah (Ardiani, 2018). Selain itu, adanya peristiwa bencana non alam seperti suatu wabah penyakit yang menyebar secara global dapat memicu pengaruh terhadap kondisi perekonomian beberapa negara. Hal tersebut diduga dapat memberikan reaksi pasar terhadap suatu informasi yang dapat dilihat dari perubahan harga saham.

Perubahan harga saham dapat diukur dengan menggunakan abnormal return. Abnormal return adalah kelebihan dari return yang sesungguhnya terjadi terhadap return normal. Return normal merupakan return ekspektasian (return yang diharapkan investor). Jadi, abnormal return adalah selisih antara return sesungguhnya yang terjadi dengan return ekspektasian (Hartono, 2017:667). Penelitian Asshodiqi (2015) yang meneliti tentang reaksi pasar modal Indonesia terhadap peristiwa pelantikan presiden tahun 2014 menemukan hasil bahwa terdapat perbedaan abnormal return yang signifikan positif. Hal yang sama ditemukan oleh penelitian Liogu dan Saerang (2015) yang meneliti tentang reaksi pasar modal Indonesia terhadap peristiwa pelantikan presiden tahun 2014 menemukan bahwa adanya abnormal return yang signifikan. Selain itu, Munajat dan 
Nurfitriana (2021) yang meneliti tentang reaksi pasar modal terhadap kebijakan tax amnesty menunjukkan bahwa terdapat perbedaan abnormal return sebelum dan sesudah peristiwa. Hasil penelitian yang serupa juga ditunjukkan dalam penelitian Kadioglu, Telceken dan Ocal (2015); Kumar (2017); Rahmawati dan Efriandy (2018); Devi dan Putra (2020).

Berbeda dengan hasil penelitian Feranita (2014) yang meneliti tentang reaksi pasar modal terhadap peristiwa bencana alam Tsunami di Aceh tanggal 26 Desember 2004 menemukan bahwa tidak terdapat perbedaan abnormal return sebelum dan sesudah peristiwa bencana Tsunami terjadi. Penelitian Bara dan Siswanto (2017) yang menganalisis tentang reaksi pasar modal Indonesia terhadap kandungan informasi pada putusan sidang kasus penistaan agama oleh Basuki Tjahaja Purnama yang menemukan bahwa tidak terdapat pengaruh signifikan terhadap abnormal return. Hal yang sama juga ditemukan oleh Wardani (2018); Pratiwi dan Wirakusuma (2018); Mubarok (2019). Berdasarkan uraian diatas, maka peneliti dapat merumuskan hipotesis sebagai berikut :

$\mathrm{H}_{1} \quad$ : Terdapat perbedaan yang signifikan pada reaksi pasar yang diukur dengan abnormal return sebelum dan sesudah Indonesia dinyatakan positif corona.

\section{Reaksi pasar yang diukur dengan trading volume activity sebelum dan sesudah Indonesia dinyatakan positif corona}

Informasi yang dipublikasikan sebagai suatu pengumuman akan memberikan sinyal bagi investor dalam pengambilan keputusan investasi. Ketika informasi diumumkan dan semua pelaku pasar sudah menerima informasi tersebut, pelaku pasar akan menginterpretasikan dan menganalisis terlebih dahulu informasi tersebut sebagai sinyal baik (good news) dan sinyal buruk (bad news) (Laili, 2017). Para investor dapat belajar dari informasi tentang saham dengan melakukan pengamatan tentang informasi volume perdagangan (Devi dan Putra, 2020). Peristiwa wabah penyakit seperti pandemi virus corona merupakan sebuah peristiwa yang dapat menimbulkan reaksi pasar. Hal ini dikarenakan dampak dari pandemi virus corona yang mengakibatkan bursa-bursa saham dunia terpengaruh termasuk pasar modal Indonesia.

Soewito, Safitri dan Suwandi (2018) dalam hasil penelitiannya menyatakan bahwa Bursa Efek Indonesia memiliki efisiensi pasar bentuk setengah kuat. Pasar dengan bentuk setengah kuat ditandai dengan adanya reaksi pasar ketika menerima informasi publik yang baru beredar. Hal ini berarti Bursa Efek Indonesia akan bereaksi terhadap informasi yang dipublikasikan. Terdapat banyak metode yang dapat digunakan untuk mengukur dampak peristiwa terhadap harga saham, salah satunya Trading Volume Activity (TVA) atau aktivitas volume perdagangan saham. Aktivitas volume perdagangan saham adalah perbandingan antara saham yang diperdagangkan pada waktu tertentu dengan jumlah saham yang beredar di pasar (Ardiani, 2018).

Penelitian Setiawan dan Bandi (2015) yang meneliti tentang reaksi pasar terhadap perubahan dividen, yaitu dividen tetap, dividen naik, dividen turun, dividen inisiasi, dan dividen omisi yang menemukan bahwa terjadi reaksi pasar secara signifikan yang ditunjukkan dengan trading volume activity. Hal yang sama ditemukan oleh penelitian Asshodiqi (2015) yang meneliti tentang reaksi pasar modal Indonesia terhadap peristiwa pelantikan presiden tahun 2014 menemukan hasil bahwa terdapat perbedaan trading volume activity yang signifikan positif. Hal serupa juga ditemukan oleh penelitian Liogu dan Saerang (2015); Pratiwi dan Wirakusuma (2018); Devi dan Putra (2020); Munajat dan Nurfitriana (2021). 
Berbeda dengan hasil penelitian Feranita (2014) yang menganalisis tentang reaksi pasar modal terhadap peristiwa bencana alam Tsunami di Aceh tanggal 26 Desember 2004 menemukan bahwa tidak terdapat perbedaan trading volume activity yang signifikan. Begitu pula dengan hasil penelitian Bara dan Siswanto (2017), Laili (2017), dan Riyadi, Sujito dan Rinawati (2019). Berdasarkan uraian diatas, maka peneliti dapat merumuskan hipotesis sebagai berikut :

$\mathrm{H}_{2} \quad$ : Terdapat perbedaan yang signifikan pada reaksi pasar yang diukur dengan trading volume activity sebelum dan sesudah Indonesia dinyatakan positif corona.

\section{Metode Penelitian \\ Periode Data}

Peristiwa terjadi pada Senin 2 Maret 2020 yang bertepatan dengan pengumuman yang disampaikan oleh Presiden Joko Widodo setelah mengonfirmasi 2 warga negara Indonesia positif corona dan dinyatakannya Indonesia sebagai salah satu negara yang terpapar virus corona sehingga jika menggunakan 5 hari sebelum dan setelah peristiwa maka waktu pengamatan dapat dimulai pada Senin 24 Februari 2020 dan berakhir pada 9 Maret 2020 sesuai dengan jadwal perdagangan saham di Bursa Efek Indonesia. Event period selama 11 hari pada masing-masing peristiwa diambil dengan harapan perubahan harga saham sudah dapat terlihat selama periode tersebut.

\section{Pengukuran Variabel \\ Abnormal Return}

Abnormal return adalah kelebihan dari return yang sesungguhnya terjadi terhadap return normal. Rumus untuk menghitung rata-rata abnormal return sebagai berikut (Hartono, 2016:680):

$\operatorname{RRTN}_{t}=\frac{\sum_{i=1}^{k} R T N_{i t}}{k}$

Dimana :

$R R T N_{t}=$ average abnormal return pada hari ke-t

$\operatorname{RTN}_{i t} \quad=$ abnormal return sekuritas-i pada hari ke-t

$k \quad=$ jumlah sekuritas yang terpengaruh oleh peristiwa

\section{Trading Volume Activity}

Trading volume activity merupakan suatu instrumen yang dapat digunakan untuk melihat reaksi pasar modal terhadap suatu informasi melalui parameter pergerakan aktivitas volume perdagangan saham di pasar modal (Andarini, 2016). Secara sistematis, aktivitas volume perdagangan dapat dirumuskan sebagai berikut :

$T V A=\frac{\sum \text { sahamperusahaanyangdiperdagangkanwaktut }}{\sum \text { sahamperusahaanyangberedarwaktut }}$

Kemudian rumus untuk menghitung rata-rata TVA sebagai berikut (Pratiwi dan Wirakusuma, 2018) : 
$X_{T V A}=\frac{\sum_{i=1}^{n} T V A_{i}}{n}$

Teknik Analisis Data

Analisis Statistik Deskriptif

Dalam penelitian ini, peneliti hanya menggunakan nilai rata-rata, standar deviasi, maksimum dan minimum. Variabel yang digunakan adalah abnormal return dan trading volume activity sebelum dan sesudah pengumuman yang diolah datanya kemudian diinterpretasikan dalam sebuah deskripsi yang mudah dipahami.

\section{Paired Sample t-Test}

Peneliti akan menggunakan paired sample t-test untuk menguji hipotesis 1 dan 2 yaitu apakah terdapat perbedaan rata-rata abnormal return dan trading volume activity sebelum dan sesudah Indonesia dinyatakan positif virus corona.

Hipotesis statistik yang digunakan dalam penelitian ini adalah :

$\mathrm{H}_{\mathrm{a} 1} \quad=$ Terdapat perbedaan yang signifikan pada reaksi pasar yang diukur dengan abnormal return sebelum dan sesudah Indonesia dinyatakan positif corona.

$\mathrm{H}_{\mathrm{a} 2}=$ Terdapat perbedaan yang signifikan pada reaksi pasar yang diukur dengan trading volume activity sebelum dan sesudah Indonesia dinyatakan positif corona.

\section{Hasil Penelitian dan Pembahasan Statistik Deskriptif}

Analisis statistik deskriptif yang diperoleh sebagai berikut :

Tabel 1. Statistik Deskriptif

\begin{tabular}{|l|c|c|c|c|c|}
\hline & N & Minimum & Maximum & Mean & $\begin{array}{c}\text { Std. } \\
\text { Deviation }\end{array}$ \\
\hline Rata-rata AR Sebelum & 42 & $-0,03551$ & 0,02849 & $-0,00527$ & 0,01127 \\
Rata-rata AR Sesudah & 42 & $-0,02753$ & 0,03085 & $-0,00460$ & 0,01303 \\
Rata-rata TVA Sebelum & 42 & 0,00044 & 0,00639 & 0,00161 & 0,00134 \\
Rata-rata TVA Sesudah & 42 & 0,00039 & 0,00644 & 0,00160 & 0,00135 \\
Valid N (listwise) & 42 & & & & \\
\hline
\end{tabular}

Sumber : Data diolah 2020

\section{Average Abnormal Return (AAR)}

Berdasarkan tabel 1, AAR sebelum pengumuman Indonesia dinyatakan positif pandemi virus corona memiliki nilai minimum yaitu sebesar $-0,03551$, nilai maksimum sebesar 0,02849, rata-rata (mean) sebesar -0,00527 dan standar deviasi sebesar 0,01127. Sedangkan AAR sesudah pengumuman Indonesia dinyatakan positif pandemi virus corona memiliki nilai minimum yaitu sebesar $-0,02753$, nilai maksimum sebesar 0,03085 , rata-rata (mean) sebesar -0,00460 dan standar deviasi sebesar 0,01303. Jika dilihat dari rata-rata average abnormal return sebelum sebesar $-0,00527$ dan sesudah sebesar 0,00460 , ini menunjukkan bahwa adanya reaksi yang ditunjukkan oleh investor dari 
sebelum sampai sesudah pengumuman peristiwa yang ditunjukkan dengan adanya peningkatan rata-rata average abnormal return meskipun masih dalam angka yang negatif.

\section{Average Trading Volume Activity (ATVA)}

Berdasarkan tabel 1, ATVA sebelum pengumuman Indonesia dinyatakan positif pandemi virus corona memiliki nilai minimum yaitu sebesar 0,00044 , nilai maksimum sebesar 0,00639, rata-rata (mean) sebesar 0,00161 dan standar deviasi sebesar 0,00134. Sedangkan ATVA sesudah pengumuman Indonesia dinyatakan positif pandemi virus corona memiliki nilai minimum yaitu sebesar 0,00039 , nilai maksimum sebesar 0,00644 , rata-rata (mean) sebesar 0,00160 dan standar deviasi sebesar 0,00135. Jika dilihat dari rata-rata average trading volume activity sebelum sebesar 0,00161 dan sesudah sebesar 0,00160 , ini menunjukkan bahwa tidak adanya reaksi oleh investor dari sebelum sampai sesudah pengumuman peristiwa yang ditunjukkan dengan tidak adanya perubahan ratarata trading volume activity.

\section{Pengujian Hipotesis}

Pengujian hipotesis digunakan untuk menguji atau membuktikan pernyataan tentang adanya perbedaan yang signifikan yang diukur dengan abnormal return dan trading volume activity sebelum dan sesudah pengumuman Indonesia dinyatakan positif pandemi virus corona. Uji hipotesis pada penelitian ini menggunakan uji paired sample ttest untuk variabel average abnormal return karena data yang diuji normalitasnya terdistribusi normal. Sedangkan untuk variabel average trading volume activity menggunakan uji wilcoxon signed ranks test karena data yang diuji normalitasnya tidak terdistribusi secara normal. Adapun hasil uji paired sample t-test untuk variabel average abnormal return pada penelitian ini sebagai berikut :

Tabel 2

\section{Hasil Uji Paired Sample T-Test}

Test Statistics ${ }^{\mathrm{a}}$

\begin{tabular}{|l|r|}
\hline & \multicolumn{2}{|c|}{ AR } \\
\hline & Rata-rata AR Sebelum - Rata-rata AR Sesudah \\
\hline T & -0.228 \\
Df & 41 \\
Sig. (2-tailed) & 0.821 \\
\hline
\end{tabular}

Sumber : Data diolah 2020

Berdasarkan uji paired sample t-test pada tabel 2 menunjukkan bahwa rata-rata abnormal return sebelum dan sesudah pengumuman Indonesia dinyatakan positif pandemi virus corona memiliki nilai signifikansi sebesar $0.821>0,05$. Tingkat signifikansi pada penelitian ini adalah $\alpha=0,05$ atau 5\%. Hal ini berarti bahwa jika nilai signifikansi lebih besar dari 0,05, maka $\mathrm{H}_{0}$ diterima dan $\mathrm{H}_{\mathrm{a}}$ ditolak. Dengan demikian, hipotesis yang diterima adalah tidak terdapat perbedaan yang signifikan pada reaksi pasar 
yang diukur dengan abnormal return sebelum dan sesudah Indonesia dinyatakan positif corona.

Sedangkan hasil uji wilcoxon signed ranks test untuk variabel average trading volume activity pada penelitian ini sebagai berikut :

Tabel 3

Hasil Uji Wilcoxon Signed Ranks Test

Test Statistics ${ }^{\mathrm{a}}$

\begin{tabular}{|l|r|}
\hline & \multicolumn{1}{|c|}{ TVA } \\
\hline & $\begin{array}{r}\text { Rata-rata TVA Sebelum - Rata- } \\
\text { rata TVA Sesudah }\end{array}$ \\
\hline Z & -0.619 \\
Sig. (2-tailed) & 0.536 \\
\hline
\end{tabular}

Sumber : Data diolah 2020

Berdasarkan hasil uji wilcoxon signed ranks test pada tabel 3 menunjukkan bahwa rata-rata trading volume activity sebelum dan sesudah pengumuman Indonesia dinyatakan positif pandemi virus corona memiliki nilai signifikansi sebesar $0.536>0,05$. Tingkat signifikansi pada penelitian ini adalah $\alpha=0,05$ atau 5\%. Hal ini berarti bahwa jika nilai signifikansi lebih besar dari 0,05 , maka $\mathrm{H}_{0}$ diterima dan $\mathrm{H}_{\mathrm{a}}$ ditolak. Dengan demikian, hipotesis yang diterima adalah tidak terdapat perbedaan yang signifikan pada reaksi pasar yang diukur dengan trading volume activity sebelum dan sesudah Indonesia dinyatakan positif corona.

\section{Pembahasan}

Informasi yang dipublikasikan sebagai suatu pengumuman akan memberikan sinyal bagi investor dalam pengambilan keputusan investasi. Ketika informasi diumumkan dan semua pelaku pasar sudah menerima informasi tersebut, pelaku pasar akan menginterpretasikan dan menganalisis terlebih dahulu informasi tersebut sebagai sinyal baik (good news) dan sinyal buruk (bad news) (Laili, 2017).

\section{Reaksi pasar yang yang diukur dengan abnormal return sebelum dan sesudah Indonesia dinyatakan positif corona}

Hasil pengujian paired sample t-test pada penelitian ini menunjukkan bahwa ratarata abnormal return sebelum dan sesudah pengumuman Indonesia dinyatakan positif pandemi virus corona memiliki nilai signifikansi sebesar 0,924>0,05. Tingkat signifikansi pada penelitian ini adalah $\alpha=0,05$ atau 5\%. Hal ini berarti bahwa jika nilai signifikansi lebih besar dari 0,05 , maka $\mathrm{H}_{0}$ diterima dan $\mathrm{H}_{\mathrm{a}}$ ditolak. Hasil pengujian ini menunjukkan bahwa tidak terdapat perbedaan yang signifikan pada reaksi pasar yang diukur dengan abnormal return sebelum dan sesudah Indonesia dinyatakan positif corona.

Hasil average abnormal return yang menunjukkan tidak adanya perbedaan yang signifikan berarti pasar tidak menunjukkan reaksi yang signifikan atas pengumuman peristiwa Indonesia dinyatakan positif pandemi virus corona. Tidak adanya perbedaan yang signifikan dikarenakan sikap para investor yang lebih menahan diri karena kondisi 
berita virus corona di Indonesia belum mencapai kondisi darurat pada sekitaran tanggal peristiwa. Investor lebih memilih untuk melihat perkembangan dari situasi yang terjadi dan memilih tindakan wait and see karena sifat kandungan informasi yang unpredictable sehingga investor tidak melakukan pembelian atau penjualan yang signifikan yang menyebabkan tidak adanya abnormal return serta untuk melihat lebih jelas apa pengaruh dari pengumuman Indonesia dinyatakan positif virus corona sebelum mengambil keputusan.

Informasi berita Indonesia dinyatakan positif pandemi virus corona ini tidak memiliki kandungan informasi yang berarti oleh investor sehingga tidak terjadi reaksi pasar. Hasil penelitian ini menunjukkan bahwa sudah terjadi efisiensi pasar dalam bentuk setengah kuat secara informasi sesuai dengan teori pasar efisien karena adanya informasi berita Indonesia dinyatakan positif pandemi virus corona ini menyebabkan adanya perubahan harga saham untuk membentuk keseimbangan harga yang baru sesuai dengan permintaan dan penawaran. Investor dapat mengakses berita secara langsung untuk memantau kondisi perkembangan dampak dari pandemi virus corona. Akan tetapi, hal tersebut tidak mengubah pandangan investor sehingga keputusan untuk membeli atau menjual saham tidak dilakukan oleh investor.

Hasil penelitian ini sejalan dengan hasil penelitian Riyadi, Sujito, dan Rinawati (2019) yang meneliti tentang reaksi pasar modal sebelum dan sesudah peristiwa upacara pembukaan Asian Games di Jakarta tidak ada perbedaan abnormal return baik sebelum maupun sesudah upacara pembukaan Asian Games di Jakarta. Selain itu, penelitian Ferranita (2014); Bara dan Siswanto (2017); Wardani (2018); Mubarok (2019) : Damayanti, Larasati dan Hana (2020); Nida (2020) menunjukkan hasil yang sama. Namun hasil penelitian ini bertolak belakang dengan penelitian yang dilakukan Rundegan, Mangantar, dan Maramis (2017) yang menunjukkan adanya perbedaan abnormal return saat sebelum dan sesudah pelantikan Sri Mulyani sebagai Menteri Keuangan pada 27 Juli 2016. Hal yang sama juga ditemukan pada penelitian Rahmawaty dan Efriandy (2018); Purwanti dan Fadholi (2019); Devi dan Putra (2020); Ismanto (2020).

\section{Reaksi pasar yang diukur trading volume activity sebelum dan sesudah Indonesia dinyatakan positif corona}

Hasil pengujian paired sample t-test pada penelitian ini menunjukkan bahwa ratarata trading volume activity sebelum dan sesudah pengumuman Indonesia dinyatakan positif pandemi virus corona memiliki nilai signifikansi sebesar 0,936 $>0,05$. Hal ini berarti bahwa jika nilai signifikansi lebih besar dari 0,05 , maka $\mathrm{H}_{0}$ diterima dan $\mathrm{H}_{\mathrm{a}}$ ditolak. Hasil pengujian ini menunjukkan bahwa tidak terdapat perbedaan yang signifikan pada reaksi pasar yang diukur dengan trading volume activity sebelum dan sesudah Indonesia dinyatakan positif corona.

Hasil average trading volume activity yang menunjukkan tidak adanya perbedaan yang signifikan berarti pasar tidak menunjukkan perubahan aktivitas volume perdagangan yang signifikan atas pengumuman peristiwa Indonesia dinyatakan positif pandemi virus corona. Tidak adanya perbedaan yang signifikan mengindikasikan bahwa investor cenderung untuk tidak melakukan transaksi perdagangan baik jual atau beli yang signifikan sehingga secara umum tidak menyebabkan adanya perbedaan yang signifikan terhadap likuiditas saham. Selain itu, investor lebih memilih tindakan wait and see karena sifat kandungan informasi yang unpredictable. Para investor tidak ingin mengambil resiko dengan terlalu cepat mengambil keputusan dari suatu informasi eksternal atau di luar peristiwa ekonomi. 
Adanya berita Indonesia dinyatakan positif pandemi virus corona ini tidak membuat adanya peningkatan aktivitas volume perdagangan saham yang signifikan. Hal ini dapat diartikan bahwa peristiwa pengumuman Indonesia dinyatakan positif pandemi virus corona ini tidak memiliki kandungan informasi yang signifikan dikarenakan saat berita virus corona diumumkan, kondisi di Indonesia belum mencapai kondisi darurat yang menyebabkan para investor masih melakukan transaksi saham pada batas wajar sehingga tidak ditemukan adanya aktivitas volume perdagangan yang berlebihan pada periode sebelum dan sesudah peristiwa. Dengan tidak adanya perbedaan volume perdagangan yang signifikan menunjukkan bahwa pasar efisien dalam bentuk setengah kuat secara informasi, tetapi tidak secara keputusan. Hal ini dapat dilihat dari informasi pengumuman yang diterima investor membuat investor tidak ingin mengambil resiko dengan terlalu cepat mengambil keputusan dari suatu informasi eksternal atau di luar peristiwa ekonomi.

Teori signaling memberikan penjelasan bahwa informasi merupakan sinyal yang dapat memberikan keyakinan bagi investor untuk pengambilan keputusan. Sinyal informasi berasal dari internal maupun dari eksternal perusahaan. Dengan pemahaman yang terbatas, investor merefleksikan sinyal tersebut menjadi sebuah keputusan ( Suharti dan Saftiana, 2021). Para investor menginterpretasikan kondisi ini sebagai suatu ketidakpastian yang mendorong adanya sikap kehati-hatian atas investasinya terhadap ketidakpastian sebuah kondisi pasar. Sikap kehati-hatian investor ini menyebabkan tidak adanya reaksi pasar yang signifikan yang ditunjukkan oleh tidak adanya perbedaan yang signifikan pada rata-rata perubahan aktivitas volume perdagangan saham. Hal ini dikarenakan para investor cenderung untuk berusaha memperoleh keuntungan dalam setiap investasinya dan selalu meminimalisir maupun menghilangkan adanya resiko kerugian dari investasinya.

Hasil penelitian ini sejalan dengan hasil penelitian Bara dan Siswanto (2017) yang meneliti tentang reaksi pasar modal terhadap peristiwa politik nasional (studi kasus pada putusan sidang kasus penistaan agama oleh Gubernur DKI Jakarta) yang menunjukkan tidak ada perbedaan trading volume activity baik sebelum maupun sesudah peristiwa. Selain itu, penelitian Maharani dan Yunita (2018); Ardani (2018); Mubarok (2019); Ismanto (2020); Nida (2020) menunjukkan hasil yang sama. Namun hasil penelitian ini bertolak belakang dengan penelitian yang dilakukan Asshodiqi (2015) yang menunjukkan adanya perbedaan trading volume activity pada reaksi pasar modal atas peristiwa pelantikan Presiden tahun 2014 pada Jakarta Islamic Index. Hal yang sama juga ditemukan pada penelitian Rundegan, Mangantar, dan Maramis (2017); Pratiwi dan Wirakusuma (2018); Devi dan Putra (2020).

\section{Simpulan}

Penelitian ini bertujuan untuk melihat dan menganalisis adanya reaksi pasar yang signifikan atas peristiwa pengumuman Indonesia dinyatakan positif pandemi virus corona yang diukur dengan indikator abnormal return dan trading volume activity. Berdasarkan hasil dan pembahasan penelitian, maka dapat ditarik kesimpulan bahwa tidak terdapat perbedaan pada average abnormal return dan average trading volume activity sebelum dan sesudah peristiwa pengumuman Indonesia dinyatakan positif pandemi virus corona.

\section{Implikasi}

Peristiwa pengumuman Indonesia dinyatakan positif pandemi virus corona dapat dianggap sebagai suatu bad news bagi pasar. Terkait hal ini, pengamatan kritis dari para investor dalam menyerap / menanggapi sinyal khususnya dalam mengambil keputusan investasi sangat diperlukan. Dengan mencermati peristiwa yang terjadi, para pelaku pasar 
dapat secara bijaksana dalam merespon dan bereaksi terhadap kandungan informasi yang diperoleh, serta lebih berhati-hati untuk melakukan transaksi di pasar.

\section{Saran}

Penelitian ini hanya berfokus pada satu peristiwa, yakni peristiwa pengumuman Indonesia dinyatakan positif pandemi virus corona tanpa mempertimbangkan peristiwa lain yang terjadi selama periode penelitian, seperti aksi korporasi pembagian dividen perusahaan. Sehingga terdapat 3 perusahaan yang tereliminasi dari populasi penelitian. Bagi investor sebaiknya dapat lebih cermat dalam membaca dan menganalisis suatu informasi yang bersumber dari luar perusahaan. Hal ini sangat penting untuk mengantisipasi dan meminimalisir kerugian yang dialami investor terlebih lagi informasi tersebut terindikasi akan berdampak negatif bagi perusahaan.

\section{Daftar Pustaka}

Andarini, D. 2016. "Analisis Reaksi Pasar Modal Terhadap Perubahan Harga BBM (Event Study Kenaikan Dan Penurunan Harga BBM Pada Perusahaan Food And Beverages yang Terdaftar Di Bursa Efek Indonesia"). Jurnal Ilmiah Mahasiswa FEB Universitas Brawijaya. Vol. 3, No. 2, 1-16.

Asshodiqi, A. 2015. "Reaksi Pasar Modal Terhadap Peristiwa Pelantikan Presiden 2014 (Event Study pada Saham LQ45, JII dan SMINFRA18)". Jurnal Ilmiah Mahasiswa FEB Universitas Brawijaya. Vol. 2. No. 3, 1-14.

Bara, F. A. dan Ely, S. 2017.” Reaksi Pasar Modal Indonesia terhadap Peristiwa Politik Nasional (Studi pada Saham LQ45 atas Putusan Sidang Kasus Penistaan Agama oleh Gubernur DKI Jakarta, Basuki Tjahaja Purnama" . Seminar Nasional Manajemen dan Bisnis ke-3 FEB Universitas Jember. 47-57.

Brunella, B., Onali, E. dan Schaeck, K. 2018. "Market Reaction to Bank Liquidity Regulation". Journal of Financial and Quantitative Analysis Univiersity of Washington. Vol. 00, No. 00, 1-37.

Bursa Efek Indonesia. 2020. Data Pasar Laporan Statistik. Jakarta. Diakses dari https://idx.co.id/data-pasar/laporan-statistik/statistik/.

Devi, Y.V. dan Putra, I.S. 2020. "Reaksi Pasar Terhadap Pengumuman Dividen Perusahaan Yang Termasuk Dalam IDX High Dividend 20 Periode 2019.” Jurnal PETA. Vol. 5 No. 2 Juli 2020 Hal 79-95 e-ISSN 2528-2581.

Damayanti, E., Larasati, R.D. dan Hana, K.F. 2020. "Reaksi Pasar Modal Indonesia terhadap Pengumuman Indonesia sebagai Negara Maju". Jurnal Ekonomi dan Manajemen POINT Vol. 2, No. 1, Juni 2020 e-ISSN : 2656-775X.

Ernawati, S.A. 2019. Studi Komparatif :" Reaksi Pasar Modal dan Pasar Modal Syariah Terhadap Kemenangan Jokowi 2019 (Jokowi's Effect)." Jurnal Manajemen dan Bisnis UTS. Vol. 2. No. 2, 8-16.

Feranita, N. V. 2014. "Reaksi Pasar Modal Indonesia Terhadap Peristiwa Bencana Alam Tsunami Di Aceh Tanggal 26 Desember 2004". Majalah Ilmiah "Dian Ilmu". Vol. 13, No. 2, 1-18.

Hartono, J. 2017. Teori Portofolio dan Analisis Investasi. Yogyakarta : BPFE Yogyakarta. 
Ismanto. I. 2020. "Reaksi Pasar Modal Terhadap Pengumuman PSBB DKI Jakarta Jilid II (Event Study LQ-45 Terdaftar BEI)". Jurnal Edueco Volume 3 No. 2 Desember 2020.

Kadioglu, E., Telceken, N. dan Ocal, N. 2015. "Market Reaction to Dividend Announcement : Evidence from Turkish Stock Market". International Business Research. Vol. 8, No. 9, 83-94.

Kumar, S. 2017. "New Evidence on Stock Market Reaction to Dividend Announcements in India". Reseacrh in International Business and Finance. No. 39, 327-337.

Laili, D. I. 2017. “ Abnormal Return dan Trading Volume Activity Sebelum Dan Sesudah Pengumuman Kenaikan Cukai Rokok Periode 2016 (Study Kasus Pada Industri Rokok Yang Terdaftar Di Bursa Efek Indonesia)". Jurnal Ilmiah Universitas Muhamadiyah Jember.

Liogu, S. J. dan Saerang. 2015. "Reaksi Pasar Modal Terhadap Pengumuman Kenaikan Harga BBM atas Saham LQ45 Pada Tanggal 1 November 2014". Jurnal EMBA Universitas Sam Ratulangi Manado. Vol. 3, No. 1, 1274-1282.

Liu, J., Sarkar, S., Kumar, S. dan Jin, Z.2016. "An Analysis of Stock Market Impact from Supply Chain Disruptions in Japan". International Journal of Productivity and Performance Management. Vol. 67. No. 1, 192-206.

Mehta, J.Y. 2014. Market Reaction to Stock Dividends : Evidence from India. Journal of VIKALPA. Vol. 39, No. 4, 55-74.

Mubarok, S. 2019. "Analisis Reaksi Pasar Saham Pada Perusahaan Penerbit Obligasi Syariah (Sukuk Korporasi) Tahun 2009-2018.” Skripsi. Universitas Islam Negeri Syarif Hidayatullah Jakarta.

Munajat, W.R. dan Nurfitriana, A. 2021. "Reaksi Pasar Modal terhadap Kebijakan Tax Amnesty (Event Study pada Perusahaan LQ45 di BEI)". Jurnal Riset Akuntansi dan Perbankan Volume 15 Nomor 1, Februari 2021 Hal 404-416 ISSN 20885008 E-ISSN 2722-4104.

Nida, D.R.P.P. 2020. "Analisis Reaksi Pasar Modal terhadap Peristiwa Pemilu Serentak tahun 2019”. WICAKSANA, Jurnal Lingkungan \& Pembangunan Vol. 4 No. 1 : Hal. 64-73 Maret 2020 ISSN: 2597-7555 E-ISSN: 2598-987 https://ejournal.warmadewa.ac.id/index.php/wicaksana.

Otoritas Jasa Keuangan. 2020. Statistik Mingguan Pasar Modal 2020. Jakarta. Diakses dari https://ojk.go.id/id/kanal/pasar-modal/data-dan-statistik/statistik-pasarmodal/Default.aspx

Pratiwi, K. R. dan Wirakusuma. 2018. "Reaksi Pasar Modal Indonesia Atas Pengumuman Kenaikan Tingkat Suku Bunga Acuan oleh Fed di AS." E-Jurnal Akuntansi Unversitas Udayana. Vol. 25, No. 3, 1966-1993.

Rahmawati, M. dan Efriandy. 2018) "Reaksi Investor Pasca Pengumuman Unsuspensi (Studi Pada Saham Perusahaan yang Terdaftar di Bursa Efek Indonesia Tahun 2013-2017)". Jurnal Manajemen dan Bisnis Sriwijaya. Vol. 16, No. 4, 265-273. 
Riyadi, S., Sujito, S. dan Rinawati. T. 2019." Reaksi Pasar Modal Sebelum dan Sesudah Peristiwa Upacara Pembukaan Asian Games 2018 Di Jakarta.” Jurnal Dinamika Sosial Budaya. Vol. 21, No. 1, 57-67.

Rundegan, J.M, Mangantar, M. dan Maramis, J.B. 2017.” Reaksi Pasar atas Pelantikan Sri Mulyani sebagai Menteri Keuangan pada 27 Juli 2016 (Studi pada Saham LQ45)". Jurnal EMBA Universitas Sam Ratulangi Manado. Vol. 5, No. 2, 27312741.

Setiawan, A. R. dan Bandi. 2015. "Reaksi Pasar Terhadap Perubahan Dividen Dengan Indikator Abnomral Return dan Trading Volume Activity". Jurnal Economica. Vol. 11, No. 2, 200-209.

Soewito, Safitri, R., Suwandi. 2018. "Analisis Model Efisiensi Pasar Bentuk Setengah Kuat Melalui Pengumuman Inisiasi Dividen pada Bank yang Terdaftar di Bursa Efek Indonesia Periode 2016." Sosialita Jurnal Ilmu Administrasi Universitas Bandar Lampung. Vol. 12, No. 2, 13-26.

Suharti, E. dan Saftiana, I.I. 2021." Reaksi Pasar dan Implikasinya terhadap Harga Saham". Jurnal MONEX Volume 10 Nomor 1 Bulan Januari Tahun 2021 ISSN: 2549-5046.

Wardani, S. K. B. 2018. "Pengaruh Peristiwa Politik (Pemilu Presiden dan Pengumuman Susunan Kabinet) Terhadap Saham Sektor Industri di Bursa Efek Indonesia". Capital Journal. Vol. 1, No. 3, 126-134. 